\title{
Chest physical therapy is effective in reducing the clinical score in bronchiolitis: randomized controlled trial
}

\section{A fisioterapia respiratória é eficaz na redução de escore clínico na bronquiolite: ensaio controlado randomizado}

\author{
Évelim L. F. D. Gomes', Guy Postiaux², Denise R. L. Medeiros ${ }^{3}$, Kadma K. D. S. Monteiro4, Luciana M. M. Sampaio5, Dirceu Costa
}

\begin{abstract}
Objective: To evaluate the effectiveness of chest physical therapy (CP) in reducing the clinical score in infants with acute viral bronchiolitis (AVB). Methods: Randomized controlled trial of 30 previously healthy infants (mean age 4.08 SD 3.0 months) with AVB and positive for respiratory syncytial virus (RSV), evaluated at three moments: at admission, then at 48 and 72 hours after admission. The procedures were conducted by blinded assessors to each of three groups: G1 - new Chest Physical therapy- nCPT (Prolonged slow expiration PSE and Clearance rhinopharyngeal retrograde - CRR), G2 - conventional Chest Physical therapy- CCPT (modified postural drainage, expiratory compression, vibration and percussion) and G3 - aspiration of the upper airways. The outcomes of interest were the Wang's clinical score (CS) and its components: Retractions (RE), Respiratory Rate (RR), Wheezing (WH) and General Conditions (GC). Results: The CS on admission was reduced in G1 (7.0-4.0) and G2 (7.5-5.5) but was unchanged in G3 (7.5-7.0). We observed a change 48 hours after hospitalization in G1 (5.5-3.0) and G2 (4.0-2.0) and in 72 hours, there was a change in G1 (2.0-1.0). Conclusion: The CP was effective in reducing the CS in infants with AVB compared with upper airway suction only. After 48 hours of admission, both techniques were effective and $\mathrm{nCPT}$ techniques were also effective in the 72 hours after hospitalization compared with cCPT techniques.

Trial Registration NCT00884429- www.clinicaltrials.gov.
\end{abstract}

Keywords: respiratory suncytial virus; bronchiolitis; physical therapy.

\section{Resumo}

Objetivo: Avaliar a efetividade da fisioterapia respiratória na redução do escore clínico em lactentes com bronquiolite viral aguda (BVA). Métodos: Ensaio controlado randomizado de 30 lactentes (média de idade 4,08 $\pm 3,12$ meses) com BVA, previamente hígidos, com vírus sincicial respiratório (VSR) positivo, avaliados em três momentos: admissão, 48 e 72 horas, antes e após os procedimentos por avaliadores cegos, em três grupos: G1 - técnicas atuais de fisioterapia (expiração lenta e prolongada e desobstrução rinofaríngea retrógrada), G2 - técnicas convencionais de fisioterapia (drenagem postural modificada, compressão expiratória, vibração e percussão) e G3 - aspiração de vias aéreas superiores por meio do escore clínico de Wang e seus componentes: retrações (RE), frequência respiratória (RR), sibilos (WH) e condições gerais (GC). Resultados: O escore clínico de Wang (CS) no momento admissão, no G1, reduziu de 7,0-4,0; no G2, de 7,5-5,5 e no G3 de 7,5-7,0, não apresentando alteração. No momento 48 horas, também houve alteração tanto no G1 (5,5-3,0) quanto no G2 (4,0-2,0) e, em 72 horas, apenas no G1 (2,0-1,0). Conclusão: A fisioterapia respiratória foi efetiva na redução do escore clínico em lactentes com BVA quando comparada com a aspiração isolada das vias aéreas na admissão. No momento 48 horas, ambas as técnicas foram efetivas, sendo que as técnicas atuais foram efetivas também nas 72 horas após a internação, comparada às técnicas convencionais.

Registro de Ensaios Clínicos NCT00884429- www.clinicaltrials.gov.

Palavras-chave: vírus sincicial respiratório; bronquiolite; fisioterapia.

Received: 12/06/2011 - Revised: 01/22/2012 - Accepted: 01/24/2012

${ }^{1}$ Healthy Department, Physical Therapy, Universidade Nove de Julho (UNINOVE), São Paulo, SP, Brazil

2 Physical Therapy Department, Grand Hôpital de Charleroi, Services de Médecine Interne et de Pédiatrie, Charleroi, Belgium

${ }^{3}$ Rehabilitation Department, Hospital Sirio Libanes, São Paulo, SP, Brazil

${ }^{4}$ Emergency Department, Universidade Federal of São Paulo (UNIFESP), São Paulo, Brazil

${ }^{5}$ Post Graduation Program Science Rehabilitation, UNINOVE, São Paulo, SP, Brazil

Correspondence to: Évelim Leal de Freitas Dantas Gomes, Av Francisco Matarazzo, 612, Laboratório de Avaliação Funcional Respiratória 1ªndar Barra Funda, CEP 05001-100, São Paulo,

SP, Brasil, e-mail: evelimgomes@uninove.br 


\section{Introduction $: \because$.}

Acute viral bronchiolitis (AVB) is the most common respiratory disease in the first year of childhood. The main agent associated with this clinical condition is the respiratory syncytial virus (RSV) whose life cycle follows seasonal peaks of disease. In Brazil, it occurs between the months of March to July. AVB is characterized by acute inflammation, edema and necrosis of the epithelial cells of small airways by increasing the production of mucus and causing bronchospasm ${ }^{1,2}$. Treatment involves two sets of AVB therapeutic procedures, a medication in order to mitigate the symptoms of the disease and physical therapy to restore bronchial permeability, pulmonary re-expansion and proper respiratory mechanics. There are controversies regarding the use of chest physical therapy (CP) in AVB; previous studies have demonstrated a lack of significant difference in length of hospital stay (LOS) and Wang's clinical score (CS $)^{3-5}$. Adverse events have been reported such as rib fractures, for example ${ }^{6,7}$. Therefore, this practice is no longer recommended.

New studies investigating pulmonary physiology in infants have led to new techniques based upon the equation of motion of breathing gases ${ }^{8}$ which follow the physiology and respect the fragility of the respiratory system. A recent French consensus ${ }^{9}$ paper and other European studies ${ }^{10,11}$ have encouraged the practice of $\mathrm{CP}$ for these infants with $\mathrm{AVB}$ as the initial treatment in order to avoid consequences such as hospitalization in intensive care units and mechanical ventilation. Despite the controversies, there are no randomized controlled trials that have yet provided sound scientific and technical evidence by comparing conventional techniques such as modified postural drainage, clapping, vibration, and expiratory chest compression with new techniques such as prolonged slow expiration (PSE) which is a slow passive and progressive expiration from the Functional Residual Capacity (FRC) into the Expiratory Reserve Volume (ERV) and clearance rhinopharyngeal retrograde (CRR) which is a forced inspiratory maneuver that aims to clear the nasopharynx indicated for infants. At the end of expiratory time the child's mouth is closed with elevation of the lower jaw, quickly clogging the orifice of the mouth and forcing thus a forced inspiration in infants with AVB. Further intervention studies are needed to provide more consistent data on the effectiveness $\mathrm{CP}$ in these infants ${ }^{12}$. Few studies have evaluated CP techniques and upper airway suction in non-intubaded infants. Etches and $\mathrm{Scott}^{13}$ found a superiority CP techniques with regards to the amount of secretion removed while Webb et al. ${ }^{3}$ did not find differences in relation to clinical score in infants with bronchiolitis. It is still not clear the action of this technique in infants but it is widely used and has no common adverse effects such as bradycardia and bleeding of nasal mucosa.
We conducted this study to investigate the hypothesis that the appropriate $\mathrm{CP}$ techniques for infants may reduce bronchial obstruction resulting from the pathological process of AVB and therefore reduce the signs and symptoms of respiratory distress and its repercussions.

\section{Methods $: \because$.}

A randomized controlled trial that was prospectively registered in Clinicaltrials.gov number NCT00884429 was conducted in the Department of Pediatrics and the Pediatric ICU at Sirio Libanes Hospital and Menino Jesus Pediatric Hospital both in São Paulo, Brazil, from March 2009 to April 2010. We included infants aged from 28 days to 24 months, previously healthy, with a clinical diagnosis of AVB and positive outcome of RSV in nasopharyngeal aspirate detected by immunofluorescence technique. We excluded infants without RSV, with a history of chronic lung disease, with a previous episode of hospitalization for wheezing, cardiac or neurological disease and those whose parents or guardians refused to sign the waiver of informed consent. Infants were randomized by using sealed opaque envelopes containing the instructions to be followed in each of three groups:

Group 1 - nCPT Chest physical therapy with new techniques, PSE and CRR.

Group 2 - cCPT Chest physical therapy with conventional techniques - vibrations, expiratory compression, modified postural drainage only in the lateral decubitus position and clapping.

Group 3 - Suction of the upper airways.

The first two groups of infants received the same techniques during hospitalization. The third group could only be assessed on admission for the following ethical reasons. At the study hospitals, all children with AVB routinely receive care with CP. Therefore, they could just receive upper airway suctioning during the hospitalization (Figure 1).

The research protocol was approved by the research and ethics committee at Sirio Libanes Hospital (number HSL2009/03, São Paulo, SP, Brazil). The assessment of infants was performed at two hours, 48 hours and 72 hours after admission and again one hour prior to discharge. Assessments were conducted by physical therapists and nurses from hospitals where the data collections were performed before and after CP using CS. Assessors were blinded to the treatment groups. These raters were trained specifically for this assessment. A recent multicenter study evaluating the CS using the same parameters (WH-wheezing, RR-respiratory rate, RE-retractions and GC-general conditions) has shown 


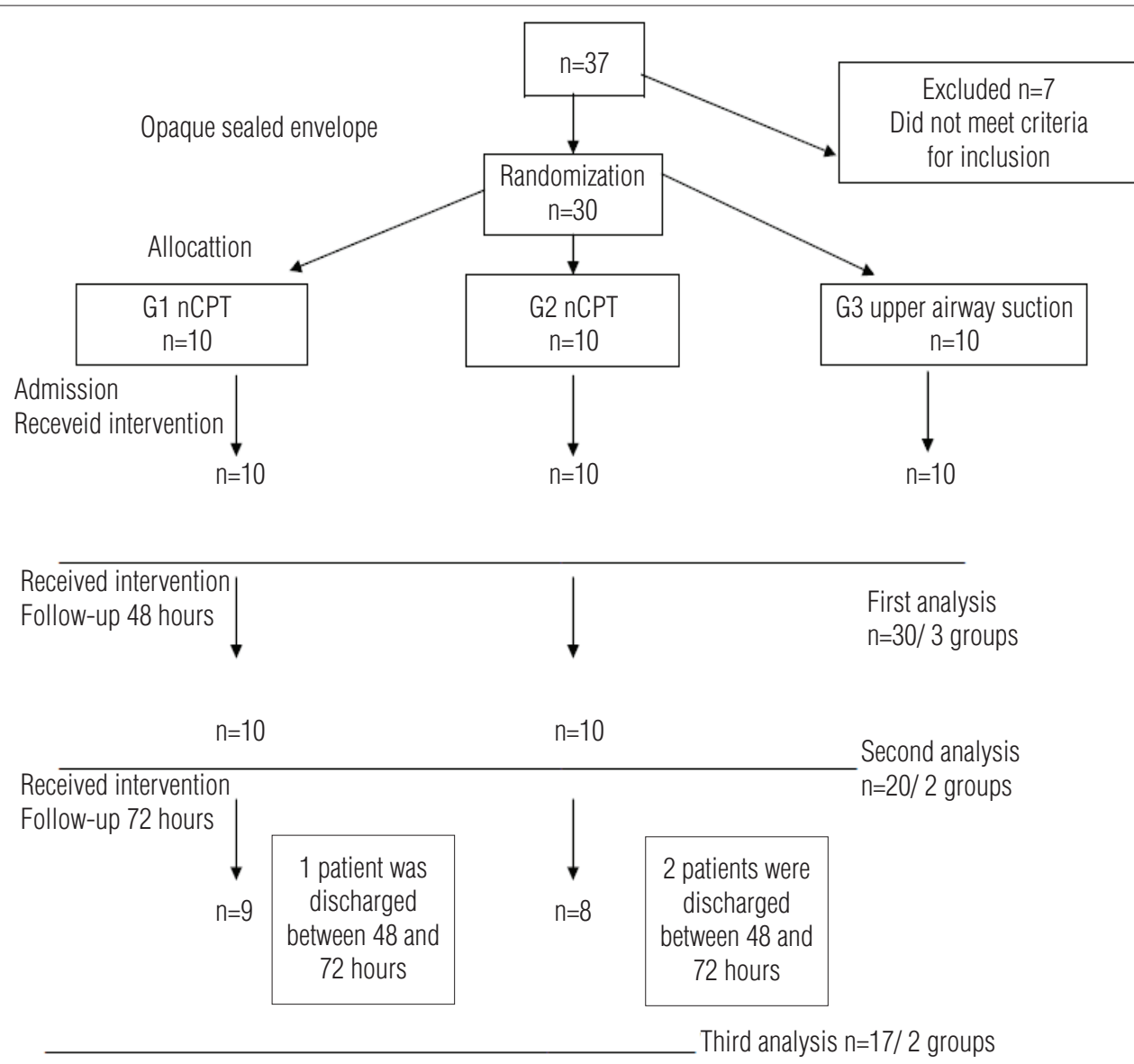

Figure 1. Reporting Trials diagram.

a high level of inter-observer agreement between physicians, nurses and respiratory therapists ${ }^{15}$. The time spent caring for children was similar in all groups and parents were unaware of their child's group allocation. The same score was used in previous studies involving the same patient population and has been demonstrated to be a reliable tool for evaluating and validating clinical outcome ${ }^{16-18}$ (Table1).

\section{Sample size}

Sample size was calculated based upon previous studies $^{19,20}$, which have found a rate of 60 to $84 \%$ improvement in gas distribution in patients with bronchiectasis and healthy individuals after undergoing conventional $\mathrm{CP}$ (postural drainage and percussion). We have assumed a minor improvement in infants $(50 \%)$ with AVB because they tend to present with fewer secretions compared with infants with bronchiectasis. Moreover, infants show a more compliant chest and an airway that is more prone to collapse than in adults ${ }^{21}$. An improvement in Wang's score in all children with bronchiolitis (100\%) after being treated with actual techniques of chest physical therapy (PSE and
CRR) was found in a Postiaux's et al. ${ }^{10}$ study, but without a control group. Another study found an initial increase in airway resistance and a reduction of the late auto PEEP by $13 \%$, which would be indicative of a reduction hyperinflation ${ }^{22}$. We have assumed, thus, an improvement in the resistance with an increase by $50 \%$ after suctioning the upper airways because infants, until the sixth month of life, present as nose breathers. Assuming a beta error of 0.1 , a power of $90 \%$ of the sample with an alpha error of 0.05 was calculated using a sample of 22 infants in total.

\section{Statistical analysis}

The distribution of the data was tested by KolmogorovSmirnov (KS) test. To investigate the primary outcome measure (CS), the nonparametric test, Kruskal-wallis (pos hoc Dunn) was used at the time of admission. Mann Whitney and Wilcoxon were calculated at 48 and 72 hours post admission. In the pre- and post-evaluation groups, the intra-Friedman test was used to assess within group evolution during the day. For variables with normal distribution such as weight, age and oxygen saturation (SpO2), we used ANOVA (pos hoc Tukey) and 
Student's $t$-test depending on the time assessed. For nominal variables, we used Fisher's exact test.

Values are expressed as medians for nonparametric variables, with minimum and maximum, mean and standard deviation for parametric variables with statistical significance considered at $\mathrm{p}<0.05$. Medcalc and Instat were used to conduct the statistical analyses.

\section{Results $: \because$.}

Thirty infants participated in the study according to the criteria described previously in two epidemic periods and were randomized in three groups according to Figure 1. Table 2 shows the characteristics of the sample. There were no between-group differences for the variables age, weight or CS at baseline showing the homogeneity of the sample (Table 2).
Medications taken in each group were also noted and no we observed a between-group difference. The days of hospitalization LOS were also similar between groups G1 and G2. Table 3 shows the median of the CS with its components (RRrespiratory rate, RE-retraction, $\mathrm{WH}$-wheezing, and GC-general conditions) upon admission for each group along with the mean and standard deviation of $\mathrm{SpO}_{2}$.

Table 3 presents that CS was significantly reduced in both G1 and G2, and the WH during this period decreased only in G1. Regarding retractions (RE), G1 decreased when comparing pre- and post-treatment and G2 showed a reduction in post-intervention compared with post hoc test G3. With a view to these results, we evaluated the effect of $\mathrm{CP}$ on G1 and G2 after 48 and 72 hours of admission. As shown in Table 4, we found significant reductions in both CS and $\mathrm{RE}$ in both groups. After 72 hours we observed significant reduction in $\mathrm{CS}$ and $\mathrm{SpO}_{2}$ only for G1.

Table 1. Wang's clinical severity score. The score assigns a value between 0 and 3 to each variable, higher scores indicates a worst condition.

\begin{tabular}{|c|c|c|c|c|}
\hline \multirow{2}{*}{ Variables } & \multicolumn{4}{|c|}{ Scores } \\
\hline & 0 & 1 & 2 & 3 \\
\hline Respiratory rate, breaths/min=RR & $<30$ & $31-45$ & $46-60$ & $>60$ \\
\hline Wheezing=WH & None & $\begin{array}{l}\text { Terminal expiratory or } \\
\text { only with stethoscope }\end{array}$ & $\begin{array}{l}\text { Entire expiration or audible on } \\
\text { expiration without stethoscope }\end{array}$ & $\begin{array}{l}\text { Inspiration and expiration } \\
\text { without stethoscope }\end{array}$ \\
\hline Retraction=RE & None & Intercostal only & Tracheosternal & Severe with nasal flaring \\
\hline General condition=GC & Normal & & & Irritable, lethargic, poor feeding \\
\hline
\end{tabular}

Table 2. Baseline demographic and clinical characteristics of each group.

\begin{tabular}{|c|c|c|c|}
\hline Variables & $\begin{array}{c}\text { G1 } \\
\text { nCPT } \\
(n=10)\end{array}$ & $\begin{array}{c}G 2 \\
\text { cCPT } \\
(n=10)\end{array}$ & $\begin{array}{c}\text { G3 } \\
\text { Suction } \\
(n=10)\end{array}$ \\
\hline Age (days) & $126.1 \mathrm{SD}=125.8$ & $157.5 \mathrm{SD}=99.26$ & $102.1 \mathrm{SD}=56.16$ \\
\hline Gender (M/F) & $4 / 6$ & $7 / 3$ & $5 / 5$ \\
\hline Wang's score (CS) & $7.0(5.0-11)$ & $7.5(3.0-10)$ & $7.5(4.0-11)$ \\
\hline Weight $(\mathrm{Kg})$ & $5.896 \mathrm{SD}=2.473$ & $7.317 \mathrm{SD}=1.987$ & $5.822 \mathrm{SD}=1.029$ \\
\hline
\end{tabular}

$\mathrm{Kg}=$ kilograms; $\mathrm{M}=$ male; F=female.

Table 3. CS before and after CP for all groups.

\begin{tabular}{|c|c|c|c|c|c|c|}
\hline \multirow[t]{2}{*}{ Variables } & \multicolumn{2}{|c|}{$\begin{array}{c}\mathrm{G} 1(\mathrm{n}=10) \\
\mathrm{nCPT}\end{array}$} & \multicolumn{2}{|c|}{$\begin{array}{c}\mathrm{G} 2(\mathrm{n}=10) \\
\mathrm{cCPT}\end{array}$} & \multicolumn{2}{|c|}{$\begin{array}{c}\text { G3 }(n=10) \\
\text { suction }\end{array}$} \\
\hline & Pre & Post & Pre & Post & Pre & Post \\
\hline CS & $7.0(5-11)$ & $4.0^{*}(2-7)$ & $7.5(3-10)$ & $5.5^{\star}(1-7)$ & $7.5(4-11)$ & $7.0(4-10)$ \\
\hline WH & $1.0(0-3)$ & $0^{*}(0-1)$ & $0.5(0-2)$ & $0(0-1)$ & $1.0(0-2)$ & $0(0-2)$ \\
\hline $\mathrm{RR}$ & $1.5(1-3)$ & $2.0(0-3)$ & $2.0(1-3)$ & $2.0(1-2)$ & $2.0(1-3)$ & $2.0(1-3)$ \\
\hline RE & $2.0(2-3)$ & $1.0^{*}(0-2)$ & $2.0(1-3)$ & $1.0^{\#}(0-2)$ & $2.0(0-3)$ & $2.0(0-3)$ \\
\hline $\mathrm{GC}$ & $3.0(0-3)$ & $3.0(0-3)$ & $3.0(0-3)$ & $3.0(0-3)$ & $3.0(0-3)$ & $3.0(0-3)$ \\
\hline $\mathrm{SpO}_{2}(\%)$ & $89( \pm 4.47)$ & $93( \pm 3.27)$ & $90.4( \pm 3.97)$ & $93( \pm 4.05)$ & $90.1( \pm 5.04)$ & $90.3( \pm 2.62)$ \\
\hline
\end{tabular}

${ }^{*} \mathrm{p}<0.05$ within-group comparison pre- vs. post-intervention; ${ }^{*} \mathrm{p}<0.05$ between-group comparison post-intervention clinical score $\mathrm{CS}$; WH=wheezing; RR=respiratory rate; RE=retraction; GC=General condition expressed (min-max); $\mathrm{SpO}_{2}$ pulse oxymetry expressed (mean $\pm \mathrm{SD}$ ). 
Table 4. CS on G1 and G2 after 48 and 72 hours pre and post CP.

\begin{tabular}{|c|c|c|c|c|}
\hline \multirow{2}{*}{$\begin{array}{l}\text { Variables } \\
\text { (48 hours) }\end{array}$} & \multicolumn{2}{|c|}{ G1 $(n=10)$} & \multicolumn{2}{|c|}{ G2 $(n=10)$} \\
\hline & Pre & Post & Pre & Post \\
\hline CS & $5.5(1-7)$ & $3.0^{*}(1-5)$ & $4.0(1-7)$ & $2.0^{*}(1-6)$ \\
\hline WH & $0(0-1)$ & $0(0)$ & $0(0-2)$ & $0(0-1)$ \\
\hline $\mathrm{RR}$ & $1.5(1-3)$ & $1.0(1-3)$ & $2.0(1-3)$ & $2.0(1-3)$ \\
\hline RE & $2.0(0-3)$ & $0^{*}(0-2)$ & $2.0(0-3)$ & $0^{\star}(0-2)$ \\
\hline GC & $0(0-3)$ & $0(0-3)$ & $0(0-3)$ & $0(0-3)$ \\
\hline $\mathrm{SpO}_{2}(\%)$ & $93( \pm 3.26)$ & $94( \pm 2.62)$ & $93( \pm 4.06)$ & $95.2( \pm 2.85)$ \\
\hline \multirow{2}{*}{$\begin{array}{l}\text { Variables } \\
\text { (72 hours) }\end{array}$} & \multicolumn{2}{|c|}{$\mathrm{G} 1(\mathrm{n}=9)$} & \multicolumn{2}{|c|}{ G2 $(n=8)$} \\
\hline & Pre & Post & Pre & Post \\
\hline CS & $2.0(0-6)$ & $1.0^{\star}(0-4)$ & $2.0(0-4)$ & $1.0(0-2)$ \\
\hline WH & $0(0)$ & $0(0)$ & $0(0)$ & $0(0)$ \\
\hline $\mathrm{RR}$ & $2.0(1-3)$ & $1.0(1-2)$ & $2.0(0-2)$ & $1.0(0-2)$ \\
\hline RE & $0(0-2)$ & $0(0)$ & $0(0)$ & $0(0)$ \\
\hline $\mathrm{GC}$ & $0(0-3)$ & $0(0-3)$ & $0(0-3)$ & $0(0-3)$ \\
\hline $\mathrm{SpO}_{2}(\%)$ & $94( \pm 2.63)$ & $96^{*}( \pm 1.32)$ & $95.2( \pm 2.90)$ & $96.3( \pm 1.07)$ \\
\hline
\end{tabular}

${ }^{*} \mathrm{p}<0.05$ within-group comparison pre- vs. post-intervention; $\mathrm{CS}=c$ linical score; WH=wheezing; RR=respiratory rate; $\mathrm{RE}=$ retraction; $\mathrm{GC}=\mathrm{General}$ condition expressed (min-max); $\mathrm{Sp} \mathrm{O}_{2}$ pulse $0 x y$ metry expressed $($ mean $\pm S D)$

\section{Discussion $: \because$.}

Bronchiolitis is a lower respiratory tract infection characterized by acute inflammation and edema together with increased mucus production and bronchospasm, affecting the flow and the permeability of the small airways and causing hyperinflation, atelectasis, wheezing and retractions ${ }^{23,24}$. This randomized controlled trial shows the benefits of the chest physical therapy $(\mathrm{CP})$ method on several scored respiratory parameters over the course of time by comparing infants with RSV bronchiolitis.

Physical therapy aims to remove secretions from the airways. To date, three randomized controlled trials have reported using conventional chest physical therapy in hospitalized patients with bronchiolitis. In those studies, no clinical benefit was found using vibration and percussion techniques ${ }^{3-5}$. Each study used clapping performed with the cupped hand for 3 minutes in 5 positions of drainage with assisted cough and/or suction. These maneuvers may not have been enough to reduce discomfort in infants.

Gajdos et al. ${ }^{25}$, conducted a multicenter clinical trial in 496 infants using the forced expiratory technique, this study showed no benefits of the CP but the primary end point was the time of randomization to the recovery of these patients. It is very important to emphasize that the forced expiratory technique should be avoided in children under 24 months of age due to high compliance tracheal and chest, because the rapid chest compression promotes an interruption of expiratory flow $^{26}$ thus demonstrating the importance of creating a modulated flow so that there is an appropriate extension of the expiratory phase and a subsequent clearance of the distal airways. Therefore, maneuvers such as tapping and postural drainage may not have been effective in pulmonary clearance of these infants because these techniques did not create a sufficient flow and forced expiratory technique for interrupting the expiratory flow, and they may increase the risk of vomiting and gastro esophageal reflux disease (GERD $)^{27-29}$. These techniques may not have influenced the reduction in hyperinflation and respiratory distress in the studies cited.

Based on these studies ${ }^{3-5}$, the American Academy of Pediatrics ${ }^{30}$ and the Cochrane Collaboration ${ }^{31}$ did not recommend conventional chest physical therapy. Still, no other study has evaluated the flow in airways using conventional techniques such as expiratory compression techniques, which are common in physical therapy practice with infants in Brazil. Uzawa and Yamaguti ${ }^{32}$ demonstrated in mechanically ventilated adults that this technique generates greater flow and volume changes in the airway compared with other conventional techniques (vibration and percussion), a factor that we believe may have been responsible for the reduction of the score in this group. However, rapid expiratory compression techniques can present several adverse effects such as rib fractures or tracheal collapse ${ }^{6,726}$. Even with these events are rare, they have to be taken in account. The actual physical therapy techniques are 
more physiologically-based and during this study, no adverse events were observed. The main component of this group of techniques is the Prolonged Slow Expiration (PSE). The obtained lung deflation helps the secretions to flow from small to larger airways where the CP takes over ${ }^{22}$. Postiaux et al. ${ }^{12}$ showed short-term benefits with PSE to some respiratory symptoms of bronchial obstruction in infants with AVB.

The impact of this specific technique, in addition to the deflation of ERV is the increase in tidal volume resulting from subsequent activation of the Hering-Breuer reflex by a prolonged expiratory time and sighs ${ }^{33-35}$, which, in the infant, is clinically important because the inherent differences between the infant and adult making the respiratory system more likely to develop muscle fatigue and discomfort. Bernard-Narbonne et al. ${ }^{11}$ showed an increase in tidal volume and $\mathrm{SpO}_{2}$ in the $\mathrm{CP}$ group of infants with AVB mechanical ventilation using slow expiratory flow as their technique of choice.

It is known that in infants there is incomplete formation of the airways and collateral ventilation system with a very compliant chest and few diaphragmatic muscle fibers resistant to fatigue that are capable of promoting instability and disadvantage in respiratory mechanics ${ }^{21,36-38}$. With this anatomy, even a small increase in tidal volume after application of PSE can reduce shrinkage and effectively reduce the score in the group in which this technique is applied. Retractions in infants with bronchiolitis are one of the most important clinical signs, and they have been the primary outcome in numerous studies ${ }^{39,40}$. There is no doubt that the reduction of this parameter deserves more attention. The upper airways suction even though it has not shown adverse effects in the course of this study, risks cannot be ruled out ${ }^{13}$ and the techniques applied to clean the upper airways such as the CRR aims to reduce the unnecessary use of the suction.

Coughing and wheezing are common symptoms of bronchial obstruction in infants, and the genesis of wheezing is in mucosal edema and to a lesser degree in bronchospasm ${ }^{41,42}$. Wheezing is explained by the oscillation of the bronchial wall and has also been called a "flutter effect" that occurs in the bronchi after the diameter has been reduced by inflammation, swelling and spasm in different structures of the bronchial wall. In children under 12 months of age, wheezing of the small airways is largely generated by mucus that partially obstructs the airflow producing the sound ${ }^{41,42}$. The treatment is directly related to their degree of reversibility and can be total, partial or none $e^{24}$. In cases of edema, hypersecretion, bronchoconstriction are treatable by applying $\mathrm{CP}$ and/or aerosol medications. Remembering that children with AVB hissing but that the pathophysiology of bronchiolitis and asthma is distinct from these infants who are less responsive to bronchodilators or steroids ${ }^{43-45}$. They are also widely used despite the presence of studies ${ }^{43,45}$ which have found no evidence for such therapies. The primary goal of $\mathrm{CP}$ in these infants is to reduce secretion obstruction and secondly respiratory distress which is a consequence of obstruction with subsequent improvement on hyperinflation and respiratory distress. This change is undoubtedly beneficial although it does not directly impact on the LOS; this has also been found in other studies ${ }^{3-5}$. A multicenter study is needed to definitively demonstrate whether these benefits of $\mathrm{CP}$ are found in infants with AVB.

Our results in different moments of assessment, both at admission and 48 hours later showed clinical improvement in infants. No adverse effects such as rib fractures were found related to the $\mathrm{CP}$, and no children were admitted to the intensive care unit or placed on ventilatory support. We, therefore, suggest that $\mathrm{CP}$ should be recommended to treat these infants. Moreover, while conventional techniques of CP have provided significant benefit to infants with AVB, it became clear that actual techniques involving PSE and CRR were effective until 72 hours after admission, a period which is characterized as critical to prevent complications such as discomfort and muscle fatigue.

\section{Limitation of the study $: \therefore$.}

The short length of hospital stay may not be enough to detect differences between the techniques, which should be different from the other studies, is that CP techniques should promote air flow and that this should not be forced because of the limitation of the flow and the trend of a dynamic collapse.

\section{Clinical implications : $:$.}

There has been an evolution in the knowledge of physiology and respiratory mechanics of infants, soon the techniques applied to this population became more subtle and when well indicated are tolerated, do not promote adverse effects and reduce respiratory impairment.

\section{Conclusion $: \because:$}

By comparing three CP protocols in infants with RSV Bronchiolitis, our study showed clinical benefits of nCPT and $\mathrm{CCPT}$ interventions. The longest benefit has been observed with nCPT without any adverse events. cCPT is suspected of rare but possible adverse events in some studies. Therefore we suggest recommending $\mathrm{nCPT}$ as the first choice for these patients. 


\section{References $: \because$.}

1. Fisher GB, Teper A, Colom AJ. Acute viral bronchiolitis and its sequelae in developing countries. Pediatr Respir Rev. 2002;3(4):298-302.

2. Bordley W, Viswanathan M, King VJ, Sutton SF, Jackman AM, Sterling L, et al. Diagnosis and testing in bronchiolitis: a systematic review. Arch Pediatr Adolesc Med. 2004;158(20):119-26.

3. Webb CSM, Martin JA, Cartlidge PHT, Gyk N, Wrigth AN. Chest Phyotherapy in acute bronchiolitis. Arch Dis Child. 1985;60:1078-9.

4. Nicholas KJ, Dhouieb MO, Marshall TG, Edmunds AT, Grant MB. An evaluation of chest physiotherapy in the management of acute bronchiolitis. Changing clinical practice. Physiotherapy. 1999;85(12):669-74.

5. Bohé L, Ferrero ME, Cuestas E, Polliotto L, Genoff M. [Indications of conventional chest physiotherapy in acute bronchiolitis]. Medicina (B Aires). 2004;64(3):198-200.

6. Gorincour G, Dubus JC, Petit P, Bourliere-Najean B, Devred P. Rib periosteal reaction: did you think about chest physical therapy? Arch Dis Child. 2004;89(11):1078-9.

7. Chanelière C, Moreux N, Pracros JP, Bellon G, Reix P. fractures costales au cours des bronchiolites aigües virales: à propos de 2 cas. Archives de Pédiatrie. 2006;13(11):1410-2.

8. Postiaux G, Ladha K, Lens E. Proposition d'une kinésithérapie respiratoire confortée par l'équation de Rohrer.Application au nourrisson broncho-obstructif. Ann Kinésithér. 1995;22(8):343-54

9. Conférence de consensus sur la prise en charge de la bronchiolitis du nourrisson. Paris, sept 2000. Arch Pediatr. 2001;8 (Suppl 1):1-196

10. Postiaux G, Dubois R, Marchand E, Demay M, Jacquy J, Mangiaracina M. Effets de la kinésithérapie respiratoire associant expiration lente prolongée et toux provoquée dans bronchiolite du nourrisson. Kinesither Rev. 2006;6(55):35-41.

11. Bernard-Narbonne F, Daoud $P$, Castaing $H$, Rousset $A$. Efficacité de la kinésithérapie respiatoire chez des enfants intubés ventilés atteints de bronchiolite aiguë. Archives de Pédiatrie. 2003;10(12):1043-7.

12. Postiaux G, Louis J, Labasse HC, Gerroldt J, Kotik AC, Lemuhot A, et al. Evaluation of an alternative chest physiotherapy method in infants with respiratory syncytial virus bronchiolits. Respir Care. 2011;56(7):989-94

13. Etches PC, Scott B. Chest physiotherapy in the newborn: effect on secretions removed. Pediatrics. 1978;62(5):713-5.

14. Wang EE, Milner RA, Navas L, Maj H. Observer agreement for respiratory signs and oximetry in infants hospitalized with lower respiratory infections. Am Rev Respir Dis. 1992;145(1):106-9.

15. Gadjos V, Beydon N, Bommenel L, Pellegrino B, de Pontual L, Bailleux S, et al. Inter-observer agreement between physicians, nurses, and respiratory therapists for respiratory clinical evaluation in bronchiolitis. Pediatr Pulmonol. 2009;44(8):754-62.

16. Sarrell EM, Tal G, Witzling M, Someck E, Houri S, Cohen HA, et al. Nebulized 3\% hypertonic saline solution treatment in ambulatory children with viral bronchiolitis decreases symptoms. Chest. 2002;122(6):2015-20

17. Beck R, Elias N, Shoval S, Tov N, Talmon G, Godfrey S, et al. Computerized acoustic assessment of treatment efficacy of nebulized epinephrine and albuterol in RSV bronchiolitis. BMC Pediatr. 2007;7:22

18. Mandelberg A, Tal G, Witzling M, Someck E, Houri S, Balin A, et al. Nebulized 3\% hypertonic saline solution treatment in hospitalized infants with viral bronchiolitis. Chest. 2003;123(2):481-7.

19. Ross J, Dean E, Abboud RT. The effect of postural drainage positioning on ventilation homogeneity in healthy subjects. Phys Ther. 1992;72(11):794-9.

20. Lamari NM, Martins ALQ, Oliveira JV, Marino LC, Valério N. Bronquiectasia e fisioterapia desobstrutiva: ênfase em drenagem postural e percussão. Rev Bras Cir Cardiovasc. 2006;21(2):206-10.

21. Sharp JT, Druz WS, Balagot RC, Baudelin VR, Danon J. Total respiratory compliance in infants and children. J Appl Physiol. 1970;29(6):775-9.
22. Morrow B, Futter M, Argent A. Effect of endotracheal suction on lung dynamics in mechanically-ventilated paediatric patients. Aust J Physiother. 2006;52(2):121-6.

23. Poustiaux G. Fisioterapia Respiratória Pediátrica. 0 tratamento guiado pela ausculta pulmonar. Porto Alegre: Artmed; 2004.

24. Bellon C. Bronchiolitis aiguë. Histoire naturelle. Arch Pédiatr. 2001;8 Suppl 1:31-8

25. Gajdos V, Katsahian S, Beydon N, Abadie V, de Pontual L, Larrar S, et al. Effectiveness of chest physiotherapy in infants hospitalized with acute bronchiolitis: A multicenter, randomized, controlled trial. PLoS Med. 2010;7(9):e1000345.

26. Postiaux G, Lens E. De ladite Accélération du Flux Expiratoire (AFE) où forced is... fast (Expiration Technique-FET). Ann Kinésithér. 1992;19(8):411-27.

27. Lannefors L, Button B, Mcllwaine M. Physiotherapy in infants and young children with cystic fibrosis: current practice and future developments. J R Soc Med. 2004;97 Suppl 44:8-25.

28. Button MB, Heine RG, Catto-Smith AG, Phelan PD, Olinsky A. Postural drainage and gastroesophageal reflux in infants with cystic fibrosis. Arch Dis Child. 1998;76(2):148-50.

29. Vandenplas Y, Diericx A, Blecker U, Lanciers S, Deneyer M. Esophageal pH monitoring data during chest physiotherapy. J Pediatr Gastroenterol Nutr. 1991;13(1):23-6.

30. Subcommitee on Diagnosis and Management of Bronchiolitis. Diagnosis and managemen of bronchiolitis. Pediatrics. 2006;118(4):1774-93

31. Perrota C, Ortiz Z, Roque M. Chest physiotherapy for acute bronchiolitis in paediatric patients between 0 and 24 months old. Cochrane Database Syst Rev. 2005;(2):CD004873.

32. Uzawa Y, Yamaguti Y. Change in lung mechanics during application of chest physiotherapy techniques. Journal of the Japanese Physical Therapy Association. 1998;25:222.

33. Lanza FC, Wandalsen G, Dela Bianca AC, Cruz CL, Postiaux G, Sole D. Prolonged slow expiration technique in infants: effects on tidal volume, peak expiratory flow, and expiratory reserve volume. Respir Care. 2011;56(12):1930-5

34. Rabbette PS, Stocks J. Influence of volume dependency and timing of airway occlusions of the Hering-Breuer reflex in infants. J Appl Physiol. 1998;85(6):2033-9.

35. Hassan A, Gossage J, Ingram D, Lee S, Milner AD. Volume of activation of the HeringBreuer inflation reflex in the newborn infant. J Appl Physiol. 2001;90(3):763-9

36. Schechter MS. Airway clearance aplications in infants and children. Respir Care. 2007;52(10):1382-91

37. Gerhardt T, Bancalari E. Chestwall Compliance in full-term and premature infants. Acta Pediatr Scand. 1980;69(3):359-64.

38. Davis GM, Coates AL, Papageorgiou A, Bureau MA. Direct measurement of static chest wal compliance in animal and human neonates. J Appl Physiol. 1988;65(3):1093-8.

39. Mansbach JM, Clark S, Christopher NC, LoVechio F, Kunz S, Acholonu U, et al. Prospective multicenter study of bronchiolitis: predicting safe discharges from the emergency department. Pediatrics. 2008;121(4):680-8.

40. Bajaj L, Turner CG, Bothner J. A randomized trial of home oxygen therapy from the emergency department for acute bronchiolitis. Pediatrics. 2006;117(3):633-40.

41. Frey $U$, Jackson AC, Silverman M. Differences in airway wall compliance as a possible mechanism for wheezing disorders in infants. Eur Respir J. 1998;12(1):136-42.

42. Gavriely N, Shee TR, Cugell DW, Grotberg JB. Flutter in flow-limited collapsible tubes: a mechanism for generation of wheezes. J Appl Physiol. 1989;66(5):2251-61.

43. Patel H, Platt R, Lozano JM, Wang EE. Glucocorticoids for acute viral bronchiolitis in infants and young children. Cochrane Database Syst Rev. 2004;(3):CD004878.

44. Mandelberg A, Amirav I. Hypertonic saline or high volume normal saline for vira bronchiolitis: mechanisms and rationale. Pediatr Pumonol. 2010;45(1):36-40.

45. Zorc JJ, Hall CB. Bronchiolitis: recent evidence on diagnosis and management. Pediatrics. 2010;125(2):342-9. 